\title{
Zorba ve Kurban Çocuk Davranışlarını Değerlendirme Formu: Güvenilirliği ve Geçerliliği
}

\section{Evaluation Form for Bully and Victim Child Behavior: Reliability and Validity}

\author{
Arzu ÖZYÜREK*, Fatma Betül KURNAZ**
}

\begin{abstract}
Öz: Akran zorbalığı davranışlarının önlenmesinde, erken yaşlardan itibaren çocuklarda zorba ve kurban davranışlarının belirlenmesi önemlidir. Bu nedenle bu çalışmada, zorba ve kurban çocuk davranışlarını değerlendirmeye yönelik bir ölçme aracı geliştirilmesi amaçlanmıştır. Çalışma grubu 176 okul öncesi ve ilkokul öğretmeninden oluşmuştur. Alan yazın ışığında oluşturulan ölçek maddelerinin kapsam geçerliği için uzman görüşünden yararlanılmıştır. Yapı geçerliğinin belirlenmesinde Açımlayıcı ve Doğrulayıcı Faktör Analizleri ve güvenilirliğin kestirilmesinde KR-20 iç tutarlılık katsayısından yararlanılmıştır. Sonuç olarak; "Zorba ve Kurban Çocuk Davranışlarını Değerlendirme Formu" ismi verilen ölçeğin "Zorba-Çocuk Davranışları", "Kurban-Çocuk Davranışları" ve "Pasif Zorba-Çocuk Davranışları" olmak üzere üç alt boyuttan ve 32 maddeden oluştuğu belirlenmiştir. Ölçek KR-20 iç tutarlılık katsayısı ZorbaÇocuk Davranışları alt boyutu için 0,86, Kurban Çocuk Davranışları alt boyutu için 0,88 ve Pasif-Zorba Çocuk alt boyutu için ise 0,71 olarak hesaplanmıştır. Ölçeğin, okul öncesi ve ilkokul döneminde zorba, kurban ve pasif zorba çocukların saptanmasında geçerli ve güvenilir veriler sunabileceği sonucuna varılmıştır.
\end{abstract}

Anahtar Kelimeler: Zorbalık, kurban, pasif-zorba, çocuk davranışları

\begin{abstract}
Identification of bullying and victim behavior in children in early ages is important to prevent peer bullying. Thus, the present study aimed to develop a measurement instrument to assess the bully and victim child behavior. The study group included 176 pre-school and primary school teachers. The scale items were designed in relation to the knowledge available in literature and field specialists were consulted for content validity. Explanatory and Confirmatory Factor Analyzes, KR-20 internal consistency coefficient were conducted to determine validity and reliability. As a result, it was determined that the scale called "Bully and Victim Child Behavior Evaluation Assessment Form" included 32 items and 3 sub-dimensions, namely "Bullying Child Behavior", "Victim Child Behavior" and "Passive Bullying Child Behavior". Scale KR-20 internal consistency coefficient was calculated as 0.86 for Bullying Child Behavior subscale, 0.88 for Victim Child Behavior subscale and 0.71 for Passive Bullying Child Behavior subscale. It was concluded that the scale can provide valid and reliable evidence for identification of bully, victim and passive-bully children during pre-school and primary school periods.
\end{abstract}

Keywords: Bullying, victim, passive-bully, child behavior

\section{Giriş}

Bireysel, sosyal ve eğitimsel bir problem olan şiddetin en önemli nedeni, toplumdaki sosyal ilişkiler olarak görülmektedir. Şiddet insanlar arasında bire bir olabileceği gibi, medya aracılığıyla veya devletler aracılığıyla da olabilir. Fiziksel, duygusal/psikolojik, sözel, cinsel, ekonomik, kültürel şiddet olmak üzere pek çok şiddet türünden söz etmek mümkündür. Şiddet bir saldırganlık biçimidir ve saldırganlık hem şiddeti hem de zorbaca eylemleri kapsamaktadır. Vurma, tekme atma gibi eylemlerin yapıldığ 1 durumlarda, zorbaca eylemler aynı zamanda şiddet olarak kabul edilmektedir (Turan, Çubukçu ve Girmen, 2010). Zorbalık, bir kişinin kasıtlı

\footnotetext{
* Prof. Dr., Karabük Üniversitesi, Sağlık Bilimleri Fakültesi, Karabük-Türkiye, ORCID: 0000-0002-3083-7202, eposta: a.ozyurek@karabuk.edu.tr

**Dr. Öğr. Üyesi, Karabük Üniversitesi, Edebiyat Fakültesi, Karabük-Türkiye, ORCID: 0000-0002-7042-2159, eposta: betulkurnaz@karabuk.edu.tr
} 
olarak başka birini rahatsız eden veya ona acı veren davranışlarda bulunması olarak tanımlanmakta ve özellikle kasıt kavramı vurgulanmaktadır. Gücün istismarı olarak ifade edilebilen zorbalıkta, güç dengesizliği de söz konusudur (Pişkin, 2002; Satan, 2006). Biyolojik ve öğrenmeyle ilgili faktörler yanında hızlı kentleşme, okullaşma oranındaki artış gibi bazı faktörler, şiddetin görülme olasılığı üzerinde etkili olmaktadır. Özellikle akran zorbalığı olarak nitelendirilen okulda şiddet görülme sıklığı, zaman içinde artış göstermiş̧ir (Turan, Çubukçu ve Girmen, 2010). Bu durum, akran zorbalığının ciddi anlamda ele alınması gereğini ortaya koymaktadır.

Zorbalık, bir veya birden fazla saldırgan öğrencinin zayıf kurbanına karşı başlattı̆ğ alay, tehdit, sataşma, vurma ve çalma gibi doğrudan davranışları içermektedir. Zorbalığın temel unsuru, tekrarlanan fiziksel ve psikolojik yıldırma sonucu süregelen rahatsızlık ve istismarın ortaya çıkmasıdır (Cardona, Reyes ve Tangalin, 2015; Yücel ve Iş1kcı, 2017). Zorbalık; vurmak ve tekmelemek gibi fiziksel, alay etmek ve küfretmek gibi sözel saldırı davranışlarını kapsayan "doğrudan zorbalık" ile kasıtlı olarak yalnız bırakma ve dışlama gibi davranışları içeren "dolaylı zorbalık" olarak sınıflandırılabilir (Karataş, 2011). Fiziksel ve sözlü zorbalık dışında, daha az yaralayıcı olduğu düşünülen bir diğer zorbalık türü de ilişkisel zorbalıktır (Costley, Sueng-Lock ve Ji-Eun, 2013). İlişkisel akran zorbalığı, kurban hakkında dedikodu ve dışlanma gibi sosyal konumu, ilişikleri ve ait olma duygusuna zarar vermek amacıyla yapılan davranışları içermektedir (Burnukara ve Uçanok, 2012). Okul öncesi eğitim kurumlarından ergenlik dönemine kadar her aşamada akran ilişkileri yoğundur. Olumlu akran etkileşimleri, çocukların sosyal gelişimine de olumlu katkı sağlar. Zorbalık, çocukluk ve ergenlik döneminde olumsuz akran ilişkilerinden biri olarak ele alınmaktadır. Akran ilişkilerinde görülen zorbalık, önceleri büyümenin bir parçası olarak doğal karşılanmıştır. Fakat görülmüştür ki, zorbalığın oldukça y1kıcı etkileri bulunmaktadır (Gültekin-Akduman, 2012; Kutlu, 2005).

Zorbalığı başlatıp sürdüren kişiler olarak tanımlanabilen zorbalar dürtüsel, saldırgan, baskın ve fiziksel açıdan güçlü olan kişilerdir, şiddet kullanmayı olumlu bir kişilik imajı olarak görürler, sürekli saldırgan davranış gösterirler. Saldırgan zorbalar aktif ve güçlü, kaygılı zorbalar ise zorbalığa katılmayıp zorbalığı başlatan kişilerdir ve güvenlik algıları zayıftır. Kurbanlar, zorbalık davranışına maruz kalan kişilerdir. Kurbanlar kendilerini değersiz hissederler, sinirli ve duyarlıdırlar. Pasif kurbanlar boyun eğerler ve kendilerine saldırıldığında öç alma eğilimindedirler, kışkırtıcı kurbanlar ise kavgayı başlatacak davranışlarda bulunan ve çabuk sinirlenen kurbanlardır. Kurbanlar kendilerini çaresiz hissederler, zorba davranışı hak ettiklerine inanırlar, enerji düzeyleri düşüktür, yaşça ve bedence zorbadan küçük olabilirler. Zorba-kurbanlar ise akranlarına karşı bazen zorba olurken bazen zorbalığa uğrayan kurban rolünde olabilirler. Zorbalardan farkları, bir saldırıya karşı tepkisel bir saldırganlık göstermeleridir. Zorbalıkta, zorbalığı izleyen ve zorbalığı durdurmayan izleyiciler zorbalığa müdahalede bulunmazken; zorbalığı durduran izleyiciler ise yakın arkadaşını korumak adına kendi güvenliklerini tehlikeye atarlar (Karataş, 2011). Olweus (2003), zorbalık olaylarındaki rolleri; zorbalığ 1 başlatan ve aktif rol oynayan "zorba", aktif rol oynayan fakat zorbalığ 1 başlatmayan "taraftar", zorbalığ 1 destekleyen fakat aktif rol oynamayan "destekleyici-pasif zorba", zorbalıktan hoşlanan fakat açık olarak desteklemeyen "pasif destekleyici-olası zorba", olayı seyreden fakat desteklemeyen "ilgili olmayan seyirci", zorbalıktan hoşlanmayan ve yeteri kadar yardımcı olmayan "muhtemel koruyan kişi”, zorbalıktan hoşlanmayan ve kurbana yardım eden "kurbanı koruyan kişi" ve zorbalığa maruz kalan kişi "kurban" olarak ele almıştır (Akt. Satan, 2006).

Zorbalık olayı, pek çok faktörden etkilenen karmaşık bir durumdur. Bireylerin gelişimini ev, okul, toplum gibi sistemler arasındaki iki yönlü etkileşim olarak gören ekolojik sistem teorisine göre, zorbalık davranışları sadece bireysel özelliklerin bir sonucu olmayıp aile, akranlar, öğretmenler ve toplumdaki diğer bireyler ve toplumdaki diğer etkilerin (kültür, medya, örfler, gelenekler vb.) sonucu oluşabilmektedir.

Zorbalığa doğrudan uğrayanlar kadar tanık olanlar da olumsuz etkilenme riski altındadırlar (Swearer ve Hymel, 2015). Akran zorbalığı yaş ve cinsiyete göre farklılık göstermektedir. Genellikle erkeklerin kızlara göre daha fazla fiziksel ve doğrudan zorbalık 
olaylarına karıştığı, kızların ise hemen göze çarpmayan dedikodu yaymak ve sosyal dışlama gibi dolaylı zorbalık olaylarında yer aldığı dikkat çekmektedir (Burnukara ve Uçanok, 2012). İlkokuldan ortaokula geçişte, aynı zamanda ergenlik dönemine geçişle birlikte zorbalığın sözel, sosyal ve cinsel davranış biçimlerinde artış görülmektedir (Cook, Williams, Guerra, Kim ve Sadek, 2010; Satan, 2006). Zorbalık davranışları ve ebeveyn tutumları arasında bir ilişki olduğu düşünülebilir. Ebeveynlik stilleri, çocuğun erken sosyalleşmesinde rol oynamaktadır ve bu açıdan düşünüldüğünde baskıcı ve otoriter tutumlu ebeveynlerin çocuklarında zorbalık oranı daha yüksek olabilir. Yine ailesiyle birlikte yaşayan çocuğa nazaran tek bir ebeveyne sahip çocukta, zorbalık davranışları görülme olasılığı daha yüksek olabilir. Olumsuz aile ortamı, ebeveynin duygusal destek eksikliği, ebeveynler arası iletişim sorunları, aile içi şiddet ve ebeveyn istismarı gibi pek çok özellik zorbalığa maruz kalmayı etkileyebilmektedir (Cardona, Reye ve Tangalin, 2015; Swearer ve Hymel, 2015). Eslea ve Smith (2000), ilkokul öğrencileri ve ebeveyn tutumlarının şiddet davranışları üzerine etkisini inceledikleri çalışmalarında, ebeveynlerin ve çocukların zorbalık tutumları arasında çok az bir ilişki olduğunu belirlemiştir. Çocukların tutumları ve davranışları arasında bir ilişki olmasına rağmen, ebeveyn tutumları çocukların davranışlarının bir habercisi olarak görülmemiştir. Özellikle okul öncesi dönemde, çocuklar anne-babalarıyla özdeşim kurarak kimliklerini ve davranış kalıplarını edinmektedirler. Her ailede çocuk yetiştirme tarzı farklıdır ve birey ailesinden edindiği öğrenme yaşantıları ve deneyimlerinden yararlanarak çevreye uyum sağlamaktadır (Emre, 2017; Özyürek, Yavuz ve Begde, 2014; Pekdoğan, 2016). Çocuklarda görülen uyum sorunlarında, aile içi iletişimin önemli olduğu dikkat çekmektedir. Korkutularak, utandırılarak, küçümsenerek, suçlu hissettirilerek eğitilen çocuklar beceriksiz, çekingen, alıngan ve ürkek olmaktadır (Begde ve Özyürek, 2016; Topçu-Kabasakal, 2005).

Tüm dünyada çocuk, ergen ve yetişkinler arasındaki zorbalık davranışları endişe uyandırmaktadır. Zorbalık, insanların birbirleriyle etkileşime girdiği aile, işyeri, okul veya mahalle gibi herhangi bir bağlamda ortaya çıkabilmektedir (Cardona, Reyes ve Tangalin, 2015). Dünya genelinde yapılan araştırmalar, zorbalığın her yaşta ve her iki cinsiyetten öğrenciler için hem zorba hem de mağdur açısından olumsuz sonuçlar ortaya çıkardığını göstermektedir. Akran zorbalığına maruz kalmak, çocuğun gelecek yaşamında psikolojik sorunlar ve uyum sorunları yaşaması açısından risk faktörü oluşturmaktadır (Costley, Sueng-Lock ve Ji-Eun, 2013; Ladd, 1990; Szexczyk-Sokolowski, Bost ve Wainwright, 2005). Akran zorbalığı şeklinde başlayan davranışlar, erken çocukluk yıllarından itibaren görülmektedir. Gültekin-Akduman (2012), çalışmasında okul öncesi dönem çocukların kendi hemcinslerine daha fazla zorbalık uyguladıklarını, erkek çocuklar arasında en sık fiziksel zorbalığın görüldüğünü ve bunun yanında sözel biçimde akran zorbalığının görüldügünü saptamıştır. Aydoğan ve Özyürek (2013) okul öncesi öğretmenleriyle yaptıkları çalışmada, özellikle fiziksel şiddetin okul öncesi sınıflarında daha yoğun olarak ve erkek çocuklarda ortaya çıktığını belirlemişlerdir. Zorbalık davranışlarının önlemesinde, davranışların ortaya çıkmadan önce tedbirlerin alınması ve risk faktörü görülen durumlarda müdahale edilmesi oldukça önemlidir. Fakat müdahalenin, çocuk gelişiminde kritik yaşlar olarak bilinen erken yıllarda yapılması gerekmektedir. Zorbalık davranışlarının, çocuklarda yerleşmesinden sonra yapılan müdahaleler etkili olamayabilir. Çocukluk ve ergenlik döneminde, zorbalığın önlenmesi veya azaltılmasına yönelik müdahale programlarının başarısının sınırlı olduğu; bu programların zorbalık davranışına değil konuyla ilgili bilginin ve algılanın değişmesine etkisi olduğu görülmektedir (Cook, Williams, Guerra, Kim ve Sadek, 2010). Kutlu (2005), çalışmasında, yedinci sınıf öğrencilerine verilen zorbalıkla başa çıkma eğitiminin zorba davranışları ve bu davranışlara maruz kalmayı azaltmada etkili olmadığını saptamıştır. Karataş (2011), zorbalığa yönelik geliştirilen programın ergenlerin zorba ve kurban olma oranlarını azaltmada etkili olmasına rağmen bu etkinin kurbanlarda uzun süre devam ettiğini, fakat zorbalarda ilk yılda anlamlı olmadığını belirlemiştir.

Zorbalık konusunda yapılan çalışmaların, ergenlik ve daha büyük yaş gruplarına yoğunlaştı̆g 1 söylenebilir. Ergenlik döneminde akranlar ön plana çıkmakta, ergenlerin akranlarıyla etkileşimleri sosyal medyanın da etkisiyle sınıftan eve taşınmakta, gece ve günün her saati kesintisiz bir biçimde sürmektedir (Ziyalar ve Çalıc1, 2017). Akranlarla olumlu 
etkileşimler çocukları fiziksel, zihinsel, sosyal ve duygusal gelişimlerine önemli katkı sağlarken olumsuz etkileşimler gelişimsel pek çok sorunlara neden olabilmektedir (Gültekin ve Akduman, 2012). Zorbalıkla ilgili çalışmalar, okulda zorbalığın önemli bir sorun olduğuna dikkat çekmektedir (Akbaba-Altun ve Erdur-Baker, 2010; Flannery, Wester ve Singer, 2004; İlhanAlper, 2008; Kapcı, 2004; Karaman-Kepenekçi ve Çınkır, 2006; Karataş, 2011; Kartal, 2009; Pişkin, 2002; Uysal ve Dinçer, 2012; Yurtal ve Cenkseven, 2007). Zorbalık ve mağduriyet, akranların bulunduğu sınıf ortamında daha olasıdır. Zorbalık, en çok okul ortamında incelenmiş, zorbalık ve kurban davranışları zayıf öğretmen-öğrenci ilişkileri ve aile katılımı eksikliğine bağlanmıştır (Swearer ve Hymel, 2015).

Zorbalık mağdurlarının yaşanan olaylardan daha çok zarar görme olasıllğı söz konusudur Düşük benlik saygısı geliştirebilirler, uyum sorunları, depresyon, okul fobisi vb. geliştirebilirler. İntihar girişimi için risk altındadırlar. Örneğin Kore'de 15 yaş üzeri bireylerin ölüm nedenleri arasında okul zorbalığının olduğu belirlenmiştir (Cook ve diğerleri, 2010; Costley, Sueng-Lock ve Ji-Eun, 2013). Kılıç (2012), çalışmasında okulda şiddete yönelen ergenlerin bu davranışlarının akranları arasında kabul görmelerinde etkili olduğu sonucuna ulaşmıştır. Delaney-Black ve arkadaşları (2002), yaptıkları çalışmada şiddete maruz kalma ile standart okul başarı testleri ve IQ testleri puanları arasında bir ilişki olduğunu saptamışlardır. Şiddete maruz kalmanın, stres olmasa bile akademik yetenek ve öğrenme potansiyeli üzerinde olumsuz etkiye sahip olabileceğini vurgulamışlardır. Gini ve Pozzolli (2013) akran zorbalığına maruz kalan ya da bu zorbalığı gerçekleştiren çocuklarda baş ya da karın ağrıları, uyku sorunları, vb. sağlık sorunlarının ortaya çıktığını belirtmiştir. Cho ve Lee (2018) ise 10-17 yaş arasındaki çocuklarla gerçekleştirdiği çalışmasında erkeklerin fiziksel zorbalığa, kızların ise sosyal ve duygusal zorbalığa daha fazla maruz kaldıklarını bulmuştur. Rupp, Elliott ve Gresham (2018), 112 ilkokul öğrencisiyle, öğrencilerin öğretmenleriyle ve anne babalarıyla yürüttükleri çalışmada, öğretmenler ile öğrenciler arasında zorbalık davranışları ve zorbalığın sıklığı konusunda farklı bir durum bildirimi olduğunu; öğrencilerin öğretmenlerin söz ettiklerinden daha fazla zorbalığa maruz kaldıklarını belirttiğini; anne babaların ile öğrencilerin bildirimleri arasında ise bir tutarlılık olduğunu anlatmışlardır. Elliott, Hwang ve Wang (2019), 554 ilkokul ve ortaokul öğrencisiyle yürüttüğü çalışmada öğrencilerdeki düşük empatik becerilerin ve yüksek dışlama davranışlarının akran zorbalığıyla güçlü ilişkiler gösterdiğini belirtmiştir. Okul öncesine devam eden çocuklarla yürütülen bir çalışmada ise zorbalığa maruz kalma ile depresyon arasında yakın ilişkiler bulunmuştur (Krygsman ve Vaillancourt, 2019).

Zorba davranışların önlenmesinde, öncelikle zorba davranışlarının belirlenmesi gerekmektedir. Şiddet ve saldırganlıkla ilgili çalışmalar incelendiğinde, bireyin kendi bildirimi veya anne-baba ve ögretmen bildirimine dayalı ve özellikle ergenlik dönemini kapsayan ölçeklerin kullanıldığ 1 dikkat çekmektedir. Bunlara örnek olarak, ergenler tarafindan yaşanan istismar seviyesini belirlemek amaciyla geliştirilen "Aile İçi Çocuk İstismarı Ölçeğì" (İşmen, 2004), aile içinde çocukların maruz kaldığı istismarı belirlemek amacıyla Türkçeye uyarlaması yapılan 8-12 yaş çocuklarına yönelik "Çocuk İstismarı Ölçeği” (Berkmen ve Okray, 2015), okul öncesi çocuğa sahip ebeveynlerin istismar potansiyellerinin belirlenmesi amaciyla geliştirilen "İstismar Farkındalık Ölçeği-Ebeveyn Formu" (Pekdoğan, 2016), Dereboy ve arkadaşları tarafından uyarlaması yapılan (1997-1998) ergenlerin yıkıcı davranışlarını belirlemede kullanılan "Conners Öğretmen ve Ebeveyn Derecelendirme Ölçekleri" (Kılıç, 2012), öğrencilerin zorbalık eğilimini belirlemek için geliştirilen "Zorbalık Davranış Eğilim Ölçeği”" ve "Akran Zorbalığı Değerlendirme Anketi" (Satan, 2006), Gültekin ve Sayıl (2005) tarafindan geliştirilen "Akran Zorbalığı Kurbanlarını Belirleme Ölçeği” ve Pekel-Uludağlı ve Uçanok (2005) tarafindan geliştirilen "Akran Zorbalarını Belirleme Ölçeği” verilebilir. Oysa okul öncesi yıllardan itibaren ergenlik dönemine kadar akran ilişkilerindeki çocukların davranışlarının belirlenmesi, ergenlikten itibaren yaşanması muhtemel problemler için önlem alınması, şiddet olaylarının giderek arttığı günümüzde erken müdahale açısından önem taşımaktadır. Bu nedenle bu çalışmada, okul öncesi ve ilkokul dönemi zorba ve kurban çocukların belirlenmesine yönelik bir ölçme aracı geliştirilmesi amaçlanmıştır. 


\section{Yöntem}

Araştırmanın bu bölümünde araştırmanın çalışma grubu, verilerin toplanması ve çözümlenmesine ilişkin bilgiler verilmiştir.

\section{Çalışma grubu}

Verilerin Karabük İlinde toplandığı çalışmada, okul öncesi ve ilkokul öğretmenleri çalışma grubunu oluşturmuştur. Değerlendirme formları okul öncesi (\%41), ilkokul 1. sinıf (\%10), 2. sinıf (\%14), 3. sinıf (\%18) ve 4. sinıf (\%17) düzeyinde öğrenim görmekte olan 176 çocuğun öğretmeni tarafından öğrencilerin sınıf içindeki davranışları dikkate alınarak doldurulmuştur. Öğrencilerin \%45'i kız, \%55'i erkektir.

\section{Veri toplama}

Ölçme aracının geliştirilmesinde öncelikle alan yazın taranmış, daha sonra iki okul öncesi ve iki ilkokul öğretmeniyle görüssme yapılarak çocuklarda zorbalık davranışlarının göstergelerinin neler olabileceği belirlenmiştir. Çocukların kendilerinden küçük ya da daha zayıf çocuklara saldırma, onlarla alay etme, zorla istemediği bir davranışı yaptırma vb. davranışların "zorbaca davranışlar" olarak tanımlandığı ve bu dönemde sıklıkla görüldüğü sonucuna ulaşılmıştır. Zorbaca davranışlarla karşılaşan çocuk ise alan yazında "kurban" olarak tanımlanmaktadır. Kurban, zorbaca davranışlar karşısında sessiz kalmakta ve istemediği halde istenen davranış1 gerçekleştirmek zorunda kaldığını hissetmektedir. Zorba ve kurban çocuklar dışında, zorba çocuğun davranışlarına seyirci kalan veya onun davranışını sürdüren çocukların varlığından da söz edilmektedir. Bu çalışmada kendisi aktif olarak zorbalık yapmasa da zorbalığa seyirci kalmayı tercih eden çocuklar "pasif-zorba çocuk" olarak tanımlanmıştır.

Sözü edilen bilgiler ışığında geliştirilecek ölçme aracının bu üç tür davranış örüntüsünü yansıtmasına ve değerlendirme formunun üç alt testten oluşmasına karar verilmiştir. Birinci alt boyutun "Zorba-Çocuk Davranışları", ikinci alt boyutun "Kurban-Çocuk Davranışları" ve üçüncü alt boyutun "Pasif Zorba-Çocuk Davranışları" olmasına karar verilmiştir. Bu doğrultuda zorba-çocuk davranışları için 13, kurban-çocuk davranışları için 14 ve pasif zorba-çocuk davranışları, için beş madde olmak üzere 32 maddelik bir madde havuzu oluşturulmuştur. Maddelerin amaca uygunluğu, anlaş1ırlığı gibi konularda yedi alan uzmanının görüşüne başvurulmuştur. Uzman görüşleri doğrultusunda mevcut maddelerdeki yazım hatalarından kaynaklanan düzeltmeler yapılmasının ardından taslak form, 32 madde ile uygulamaya hazır hale getirilmiştir.

\section{İșlem}

Verilerin toplanmasında, taslak formun okul öncesi ve ilkokul sınıf öğretmenleri aracıllğıyla en az 100 okul öncesi ve 200 ilkokul öğrencisi için doldurulması hedeflenmiştir. Karabük Valiliği onayı alındıktan sonra Karabük Merkez ilçesinde yer alan anaokulu ve ilkokullardan rastlantısal olarak seçilen beş bağımsız anaokulu ve on ilkokul ziyaret edilmiştir. Çalışmaya katılmaya gönüllü öğretmenlerden sık sık ya da ara sıra zorbaca davranışlar sergileyen ya da genellikle kurban olan iki kız ve iki erkek olmak üzere dört çocuk için formda yer alan maddeleri işaretlemeleri istenmiştir. Formları doldururken zorba ya da kurban olduğu düşünülen çocuklar için tüm maddelerin doldurulması istenmiştir. Öğretmenler, sınıflarından iki veya dört çocuk için formu doldurmuşlardır. Toplanan 176 formdan elde edilen bilgiler bilgisayar ortamına girilmiştir.

\section{Verilerin analizi}

Yap1 geçerliği için Açımlayıcı Faktör Analizi (AFA) ve Doğrulayıcı Faktör Analizi (DFA) yapılmıştır. AFA, birbiriyle ilişkili değişkenlerin, kavramsal olarak anlamlı daha az sayıda yeni değişkenleri keşfetmeyi; DFA, kuramsal bir yapıya dayalı olarak geliştirilen bir ölçme aracından elde edilen verilerin, belirlenen yapıya uyumunu değerlendirmeyi sağlayan bir istatistiksel 
tekniktir (Çokluk, Şekercioğlu ve Büyüköztürk, 2014). Madde ayırıcılı̆̆ının incelenmesinde alt ve üst \%27'lik dilimlerin madde puanları arasındaki fark karşılaştırılmıştır (Baykul, 2000). Güvenirlik katsayı için KR-20 güvenirlik katsayısından yararlanılmıştır.

\section{Bulgular}

$\mathrm{Bu}$ bölümde, geliştirilen ölçme aracının geçerlik ve güvenirlik çalışmalarına ilişkin bulgular verilmiştir.

Değerlendirme formunun uygulanmasından elde edilen verilerin güvenirliğine ilişkin bulgular KR-20 iç tutarlılık katasıyı hesaplanarak araştırılmış ve sonuçlar Tablo 1'de verilmiştir. KR-20 iç tutarlılık katsayısı Zorba Çocuk Davranışları alt boyutunda 0,86, Kurban Çocuk Davranışları alt boyutunda 0,88 ve Pasif-Zorba Çocuk Davranışları alt boyutunda ise 0,71 olarak hesaplanmıştır. Bu değeler değerlendirme formundan elde edilen sonuçların güvenilir olduğunu göstermektedir.

Tablo 1.

Testten Elde Edilen Puanlara İlişkin İç Tutarlılık Katsayısı

\begin{tabular}{lc}
\hline Alt Boyut & İç tutarlııık Katsayısı (KR-20) \\
\hline Zorba Çocuk Davranışları & 0,86 \\
Kurban Çocuk Davranışları & 0,88 \\
Pasif-Zorba Çocuk Davranışları & 0,71 \\
\hline
\end{tabular}

Değerlendirme formunun faktör yapısının belirlenmesi ve faktör yük değerlerinin belirlenmesi amacıyla elde edilen veriler üzerinde Açımlayıcı Faktör Analizi (AFA) yapılmıştır. Her alt boyut maddeleri için AFA ayrı ayrı gerçekleştirilmiştir. Verilerin normal bir dağılımdan gelip gelmediği Barlett Küresellik Testi, verilerin faktör analizine uygunluğu ise Kaiser-MayerOlkin (KMO) ile incelenmiştir. Her üç alt boyutta yer alan maddeler için elde edilen değerler Tablo 2'de verilmiştir.

Tablo 2.

Alt Boyutlardan Elde Edilen Verilerin KMO Değeri ve Barlett'in Küresellik Testi sonuçları

\begin{tabular}{lcc}
\hline Alt Boyutlar & Kaiser-Mayer-Olkin & Barlett'in Küresellik Testi \\
\hline Zorba Çocuk Davranışları & 0,90 & $\chi^{2}=1429, \mathrm{df}=78, \mathrm{p}=.000$ \\
Kurban Çocuk Davranışları & 0,95 & $\chi^{2}=1773, \mathrm{df}=91, \mathrm{p}=.000$ \\
Pasif-Zorba Çocuk Davranışları & 0,76 & $\chi^{2}=254, \mathrm{df}=10, \mathrm{p}=.000$ \\
\hline
\end{tabular}

Tablo 2 incelendiğinde KMO değerinin 0,60'tan daha yüksek çıkması, verilerin faktörleştirmeye uygun olduğunun, Barlett'in Küresellik testinin manidar $(p<0,05)$ çıkması, dağglımın normalliğinin bir kanıtı olarak yorumlanabilir (Büyüköztürk, 2017). Tablo 1'de elde edilen sonuçlar ilgili ölçütle karşılaştırıldığında, verilerin AFA için uygun olduğuna karar verilmiştir.

Verilerin çözümlenmesinin ardından maddelerin çıkartma değerleri incelenmiş ve çıkartma değerlerinin Zorba-Çocuk Davranışları için 0,48 ile 0,69; Kurban-Çocuk Davranışları için 0,44 ile 0,74; Pasif Zorba-Çocuk Davranışları için 0,42 ile 0,63 arasında değerler aldığ 1 görülmüştür. Madde çıkartma değerinin 0,10 'dan daha büyük olması beklenmektedir (Büyüköztürk, 2017). Bu durum maddelerin ilk aşamada önemli bir sorun barındırmadığını düşündürmüştür. Sonraki aşamada üç farklı boyutta yer alan maddelere ait birikinti grafiği incelenmiş ve sonuçlar Şekil 1'de verilmiştir. 


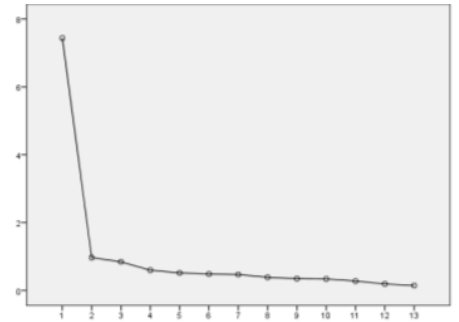

Zorba-Çocuk Davranışları maddeleri verilerine ilişkin birikinti grafiği

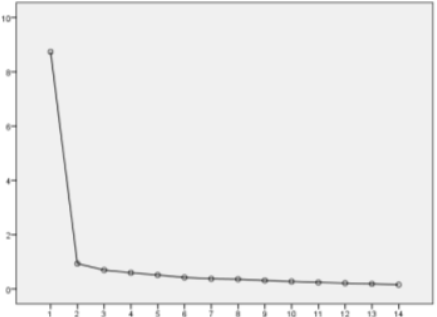

Kurban-Çocuk Davranışları maddeleri verilerine ilişkin birikinti grafiği

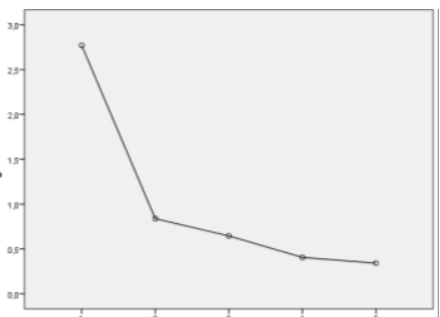

Pasif Zorba-Çocuk Davranışları maddelerine ilişkin birikinti grafiği

Şekil 1. Alt Testlerin Uygulanmasından Elde Edilen Verilere Ait Birikinti Grafikleri

Şekil 1 incelendiğinde, grafiklerin tümünde birinci faktörden sonra yüksek ivmeli bir düşüş olduğu, ikinci ve sonraki faktörlerden sonra grafiğin yatay bir eksende devam ettiği görülmektedir. İkinci ve sonraki faktörlerin varyansa katkıları benzer olduğundan, ilgili maddelerin tek faktörlü bir yapıyı temsil ettiğine karar verilmiştir. Değerlendirme formunun geliştirilmesi aşamasında da her alt boyut için tek faktörlü bir yapıya uygun olacak biçimde maddeler yazıldığından, elde edilen bu sonuçların ölçme aracının geliştirilmesi aşamasındaki kuramsal yapıyı da temsil ettiği sonucuna ulaşılmıştır. Değerlendirme formunun tek faktörlü olduğuna ilişkin bir diğer kanıt da öz değeri 1'den yüksek kaç faktör olduğu ve bu faktörlerin açıkladıkları toplam varyanstır. Bu nedenle bu aşamada, alt boyutlarda öz değerleri 1'den büyük olan faktörler ve bu faktörlerin açıkladıkları toplam varyanslar incelenmiş ve Tablo 3 'te verilmiştir.

Tablo 3.

Değerlendirme formunun maddelerine ilişkin öz değerler ve açıklanan varyans

\begin{tabular}{llcc}
\hline Alt Boyutlar & & Birinci Faktör & İkinci Faktör \\
\hline \multirow{3}{*}{ Zorba Çocuk Davranışları } & Öz değeri & 7,44 & 0,96 \\
& Açıladığı Varyans & 57,23 & 7,44 \\
& Açılanan Toplam Varyans & 57,23 & 64,67 \\
\hline \multirow{3}{*}{ Kurban Çocuk Davranışları } & Öz değeri & 8,73 & 0,93 \\
& Açılladığı Varyans & 62,41 & 6,65 \\
& Açılanan Toplam Varyans & 62,41 & 69,07 \\
\hline \multirow{3}{*}{ Pasif-Zorba Çocuk Davranışları } & Öz değeri & 2,77 & 0,83 \\
& Açıladığı Varyans & 55,39 & 16,75 \\
& Açılanan Toplam Varyans & 55,39 & 72,15 \\
\hline
\end{tabular}

Tablo 3 incelendiğinde, tüm alt boyutlarda öz değeri 1'den büyük ikinci bir faktörün olmadığ 1 görülmektedir. Ayrıca tüm alt testlerde birinci faktörün açıkladığı varyans oranı $\% 50$ 'den daha büyüktür. Tek faktörlü testlerde açıklanan toplam varyans oranının \%30'un üzerinde olması yeterli görülmektedir (Büyüköztürk, 2017). Elde edilen sonuçlara ait madde faktör yük değerleri Tablo 4 'te verilmiştir.

Tablo 4.

Maddelere ilişkin faktör yük değerleri

\begin{tabular}{|c|c|c|c|c|c|c|c|}
\hline Madde & $\begin{array}{l}\text { Faktör yük } \\
\text { değeri }\end{array}$ & \multirow{5}{*}{ 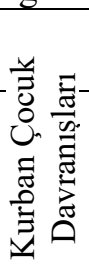 } & Madde & $\begin{array}{l}\text { Faktör yük } \\
\text { değeri }\end{array}$ & \multirow{6}{*}{ 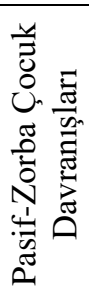 } & Madde & $\begin{array}{l}\text { Faktör yük } \\
\text { değeri }\end{array}$ \\
\hline 10 & 0,83 & & 4 & 0,86 & & 2 & 0,79 \\
\hline 4 & 0,81 & & 9 & 0,85 & & 5 & 0,78 \\
\hline 8 & 0,80 & & 3 & 0,84 & & 4 & 0,76 \\
\hline 13 & 0,76 & & 8 & 0,83 & & 3 & 0,72 \\
\hline 3 & 0,76 & & 11 & 0,83 & & 1 & 0,65 \\
\hline
\end{tabular}




\begin{tabular}{ccccc}
9 & 0,75 & 2 & 0,82 \\
11 & 0,75 & 6 & 0,81 \\
6 & 0,73 & 7 & 0,80 \\
7 & 0,73 & 12 & 0,77 \\
5 & 0,73 & 10 & 0,77 \\
1 & 0,72 & 1 & 0,75 \\
2 & 0,72 & 5 & 0,72 \\
12 & 0,69 & 13 & 0,70 \\
& & 14 & 0,67 \\
\hline
\end{tabular}

Tablo 4'e göre, Zorba-Çocuk Davranışları alt boyutunda 13 maddenin 0,83 ile 0,67, Kurban-Çocuk Davranışları alt boyutunda 14 maddenin 0,86 ile 0,67 ve Pasif Zorba-Çocuk Davranışları alt boyutunda beş maddenin 0,79 ile 0,65 arasında faktör yük değeri verdiği görülmektedir. Binişik ve düşük faktör yük değeri veren maddelerin olmaması 32 maddelik üç alt boyuttan oluşan ölçme aracının yapıyı iyi bir biçimde temsil ettiğine ilişkin kanıtlar sunmaktadir.

AFA'dan sonra, model uyumunu test etmek amaciyla elde edilen sonuçlar üzerinde DFA uygulanmış ve sonuçlar Tablo 5'te verilmiştir.

Tablo 5.

Elde Edilen Verilerin DFA Sonuçları

\begin{tabular}{lccc}
\hline & $\begin{array}{c}\text { Zorba Çocuk } \\
\text { Davranışları }\end{array}$ & $\begin{array}{c}\text { Kurban Çocuk } \\
\text { Davranışları }\end{array}$ & $\begin{array}{c}\text { Pasif-Zorba Çocuk } \\
\text { Davranışları }\end{array}$ \\
\hline$\chi^{2}$ & 205 & 278,0 & 18,6 \\
sd & 65,0 & 77,0 & 5,0 \\
$\chi^{2} /$ sd & 3,15 & 3,56 & 3,7 \\
CFI & 0,96 & 0,96 & 0,95 \\
GFI & 0,85 & 0,82 & 0,96 \\
RMR & 0,01 & 0,01 & 0,01 \\
SRMR & 0,05 & 0,05 & 0,05 \\
\hline
\end{tabular}

Tablo 5 incelendiğinde, bulguların modeli doğruladığ görülmektedir. $\chi^{2} / \mathrm{sd}$ değerinin büyük örneklemlerde 5'ten küçük olması kabul edilebilir uyumu, CFI değerinin 0,90 ve üzerinde olması iyi uyumu (Tabachnick, Fidell ve Osterlind, 2001), GFI değerinin 0,90 ve üzerinde olması iyi uyumu, RMR değerinin 0,05 ve küçük olması mükemmel uyumu, SRMR değerinin 0,08 ve küçük olmas1 iyi uyumu (Brown, 2014) göstermektedir. Bu ölçütler doğrultusunda, Tablo 4 'te yer alan sonuçlarla modelin doğrulandığı söylenebilir.

\section{Madde-Toplam Puan Korelasyonları}

Madde toplam puan korelasyonu, maddelerin toplam puanla olan ilişkisini vermektedir. Testin iç tutarlılığıyla yakından ilişkili bu değerin 0,30 ve üzeri olması beklenir (Büyüköztürk, 2017). Tablo 6' da üç alt boyuttaki maddelere ait madde toplam puan korelasyonları (r) verilmiştir.

Tablo 6.

Değerlendirme Formunda Yer Alan Maddelerin Madde Toplam Puan Korelasyonları

\begin{tabular}{lc}
\hline Zorba Çocuk Davranışları-Maddeler & $\mathrm{r}$ \\
\hline S1klıkla arkadaşının oynadı̆̆ı oyuncağı veya bir eşyasını zorla elinden alır. & 0,67 \\
Genellikle arkadaşlarına ait malzemelere zarar verir (yırtar, kırar vb.) & 0,66 \\
Sıra olmayı gerektiren durumlarda, daima sıradaki arkadaşını iterek onun önüne geçmeye & 0,71 \\
& \\
çalışır. & 0,76 \\
Çoğu zaman haksız olduğu durumlarda da haklı çıkmak için arkadaşına bağırır. & 0,67 \\
Genellikle arkadaşlarıyla ilişkilerinde alaycıdır (dalga geçer, isim takar vb.)
\end{tabular}


S1klıkla arkadaşı oyuna girmek istediğinde onu oyuna almaz.

Sınıftaki bir grup arkadaşına, bir başka arkadaşını oyuna almamaları için sürekli telkinde $\quad 0,68$ bulunur.

Çoğu zaman arkadaşına zarar verici davranışta (vurma, tükürme, saçını çekme vb.) 0,75 bulunur.

Her zaman kızgınlığını küfrederek ya da aşağılayıcı söz söyleyerek belirtir.

0,70

Arkadaşına karşı rahatsız edici davranışları (çimdikler, vurur, vb.) genellikle öğretmen $\quad 0,80$ görme alanının dışındayken gerçekleştirir.

Çoğu zaman zarar verici davranışlarda bulunan kendi olmasına rağmen, arkadaşını 0,71 öğretmenine şikâyet eder.

Arkadaşı üzgün ve mutsuz olduğunda, bu duruma sevindiğini gösteren davranışları (güler, $\quad 0,64$ alay eder vb.) s1kl1kla gösterir

Genellikle haksız olduğunu bildiği halde, haklı olan arkadaşını öğretmenine veya anne- $\quad 0,72$ babasına şikâyet etmekle tehdit eder.

Kurban Çocuk Davranışları -Maddeler

Oyuncağı veya bir eşyası zorla elinden alındığında bu duruma göz yumar.

Başka bir arkadașı tarafından eșyalarına zarar verildiğinde (yırtma, kırma vb.) sessiz kalır. $\quad 0,78$

Sıra olmayı gerektiren durumlarda sırayı bozup önüne geçen arkadaşına itiraz etmez. $\quad 0,81$

Haklı olduğunu bildiği halde, kendine bağıran arkadaşının sözde haklılığını kabul eder. $\quad 0,83$

Kendisiyle alay edildiğinde (dalga geçildiğinde, isim takıldığında vb.) ağlar veya sessiz $\quad 0,68$ kalir.

Arkadaş1 onu oyuna almak istemediğini belirttiğinde sebebini sorgulamaz. $\quad 0,77$

Bir arkadaşı, gruptaki diğer çocuklara onu oyuna almamaları konusunda telkinde 0,77

bulunduğunda sessiz kalır.

Arkadaşı kendine zarar verdiğinde (vurduğunda, tükürdüğünde, saçını çektiğinde vb) $\quad 0,79$ sessiz kalır.

Kendine küfreden ya da aşağılayıcı söz söyleyen arkadaşına tepki göstermez.

Öğretmeninin görme alanı dışındayken kendini rahatsız eden arkadaşından şikayetçi 0,72

olmaz.

Arkadașı tarafindan öğretmenine șikâyet edildiğinde, mağdur olan kendi olmasına rağmen $\quad 0,80$

bu duruma sessiz kalır.

Kendi üzüntü ve mutsuzluğuna sevinen arkadaşlarına tepki göstermez.

Öğretmenine veya anne-babasına şikâyet etmekle tehdit eden arkadaşının, isteklerini 0,66 yerine getirme eğilimi gösterir.

Diğerleri tarafından tercih edilmediğinde, etkinliklerini tek başına sürdürmeyi kabullenir. $\quad 0,63$

Pasif-Zorba Çocuk Davranışları-Maddeler

Arkadaşı diğer bir arkadaşına ya da arkadaşının eşyasına zarar verdiğinde aynı davranışa $\quad 0,47$

katılır/davranışı sürdürür.

Arkadaşlarından biri diğerine sözlü şiddet (bağırma, küfretme, vb.) uyguladığında kendisi $\quad 0,64$

bu duruma sessiz kalır.

Arkadaşlarından biri oyuna alınmadığında bu duruma sessiz kalır.

Tablo 6 incelendiğinde, Zorba Çocuk Davranışları alt boyutunda 13 maddenin maddetoplam puan korelasyonlarının 0,64 ile 0,80, Kurban Cocuk Davranıșları alt boyutunda 14 maddenin 0,83 ile 0,63, Pasif-Zorba Çocuk Davranışları alt boyutunda beș maddenin 0,47 ile 0,64 aralığında değiştiği görülmektedir. Bu değerler tüm alt boyutlardaki maddelerin tutarlı bir özelliği ölçtüğüne ilişkin kanıtlar sunmaktadır.

Maddelerin \%27'lik üst ve \%27'lik alt grupta aldığ 1 değerlerin manidar düzeyde farklılaşıp farklılaşmadığına ilişkin yapılan testler de maddelerin ayırıcılığının bir ölçüsüdür. Üst ve alt grupta madde puanlarının karşılaştırılmasına ilişkin t-Testi sonuçları Tablo 7'de verilmiştir. 
Tablo 7.

Üst ve Alt Grupta Madde Puanlarının Karşılaştırılmasına İlişkin T-Testi Sonuçları

\begin{tabular}{|c|c|c|c|c|c|c|c|c|}
\hline & Madde & $\begin{array}{l}\text { Grup } \\
(\% 27)\end{array}$ & $\mathrm{N}$ & $\bar{x}$ & $S_{X}$ & $\mathrm{t}$ & $\mathrm{df}$ & $\mathrm{p}$ \\
\hline \multirow{28}{*}{ 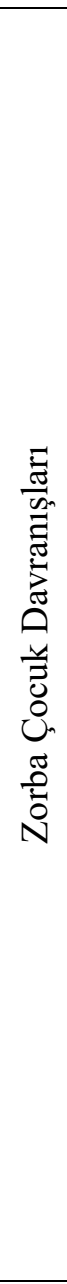 } & \multirow{2}{*}{ M1 } & Üst & 45 & 2,00 & 0,00 & \multirow[t]{2}{*}{13,26} & \multirow[t]{2}{*}{88} & \multirow[t]{2}{*}{.000} \\
\hline & & Alt & 45 & 1,20 & 0,40 & & & \\
\hline & \multirow{2}{*}{ M2 } & Üst & 45 & 2,00 & 0,00 & \multirow[t]{2}{*}{9,87} & \multirow[t]{2}{*}{88} & \multirow[t]{2}{*}{.000} \\
\hline & & Alt & 45 & 1,31 & 0,46 & & & \\
\hline & \multirow{2}{*}{ M3 } & Üst & 45 & 2,00 & 0,00 & \multirow[t]{2}{*}{24,81} & \multirow[t]{2}{*}{88} & \multirow[t]{2}{*}{.000} \\
\hline & & Alt & 45 & 1,06 & 0,25 & & & \\
\hline & \multirow{2}{*}{ M4 } & Üst & 45 & 2,00 & 0,00 & \multirow[t]{2}{*}{24,81} & \multirow[t]{2}{*}{88} & \multirow[t]{2}{*}{.000} \\
\hline & & Alt & 45 & 1,06 & 0,25 & & & \\
\hline & \multirow{2}{*}{ M5 } & Üst & 45 & 2,00 & 0,00 & \multirow[t]{2}{*}{11,00} & \multirow[t]{2}{*}{88} & \multirow[t]{2}{*}{.000} \\
\hline & & Alt & 45 & 1,26 & 0,44 & & & \\
\hline & & Üst & 45 & 2,00 & 0,00 & 15,45 & 88 & .000 \\
\hline & M6 & Alt & 45 & 1,15 & 0,36 & & & \\
\hline & & Üst & 45 & 2,00 & 0,00 & 16,91 & 88 & .000 \\
\hline & M7 & Alt & 45 & 1,13 & 0,34 & & & \\
\hline & & Üst & 45 & 2,00 & 0,00 & 18,76 & 88 & .000 \\
\hline & M8 & Alt & 45 & 1,11 & 0,31 & & & \\
\hline & & Üst & 45 & 2,00 & 0,00 & 9,38 & 88 & .000 \\
\hline & M9 & Alt & 45 & 1,33 & 0,47 & & & \\
\hline & & Üst & 45 & 2,00 & 0,00 & 44,00 & 88 & .000 \\
\hline & M10 & Alt & 45 & 1,02 & 0,14 & & & \\
\hline & & Üst & 45 & 2,00 & 0,00 & 18,76 & 88 & .000 \\
\hline & M11 & Alt & 45 & 1,11 & 0,31 & & & \\
\hline & & Üst & 45 & 2,00 & 0,00 & 8,12 & 88 & .000 \\
\hline & M12 & Alt & 45 & 1,40 & 0,49 & & & \\
\hline & & Üst & 45 & 2,00 & 0,00 & 18,76 & 88 & .000 \\
\hline & 1013 & Alt & 45 & 1,11 & 0,31 & & & \\
\hline & Toplam & Üst & 45 & 26,00 & 0,00 & 34,11 & 88 & .000 \\
\hline & puan & Alt & 45 & 15,28 & 2,10 & & & \\
\hline & & Üst & 45 & 2,00 & 0,00 & 11,66 & 88 & .000 \\
\hline & MI & Alt & 45 & 1,24 & 0,43 & & & \\
\hline & & Üst & 45 & 2,00 & 0,00 & 15,45 & 88 & .000 \\
\hline & M2 & Alt & 45 & 1,15 & 0,36 & & & \\
\hline & & Üst & 45 & 2,00 & 0,00 & 21,23 & 88 & .000 \\
\hline & M3 & Alt & 45 & 1,08 & 0,28 & & & \\
\hline $\bar{\Xi}$ & M4 & Üst & 45 & 2,00 & 0,00 & 15,45 & 88 & .000 \\
\hline$\sum^{\pi}$ & 1014 & Alt & 45 & 1,15 & 0,36 & & & \\
\hline صี & & Üst & 45 & 2,00 & 0,00 & 15,45 & 88 & .000 \\
\hline$\underline{\vec{y}}$ & MI & Alt & 45 & 1,15 & 0,36 & & & \\
\hline 8 & & Üst & 45 & 2,00 & 0,00 & 24,81 & 88 & .000 \\
\hline U. & M6 & Alt & 45 & 1,06 & 0,25 & & & \\
\hline : & & Üst & 45 & 2,00 & 0,00 & 18,76 & 88 & .000 \\
\hline$\Xi$ & M7 & Alt & 45 & 1,11 & 0,31 & & & \\
\hline & & Üst & 45 & 2,00 & 0,00 & 12,41 & 88 & .000 \\
\hline & M8 & Alt & 45 & 1,22 & 0,42 & & & \\
\hline & M9 & Üst & 45 & 2,00 & 0,00 & 12,41 & 88 & .000 \\
\hline & M9 & Alt & 45 & 1,22 & 0,42 & & & \\
\hline & M10 & Üst & 45 & 2,00 & 0,00 & 12,41 & 88 & .000 \\
\hline
\end{tabular}




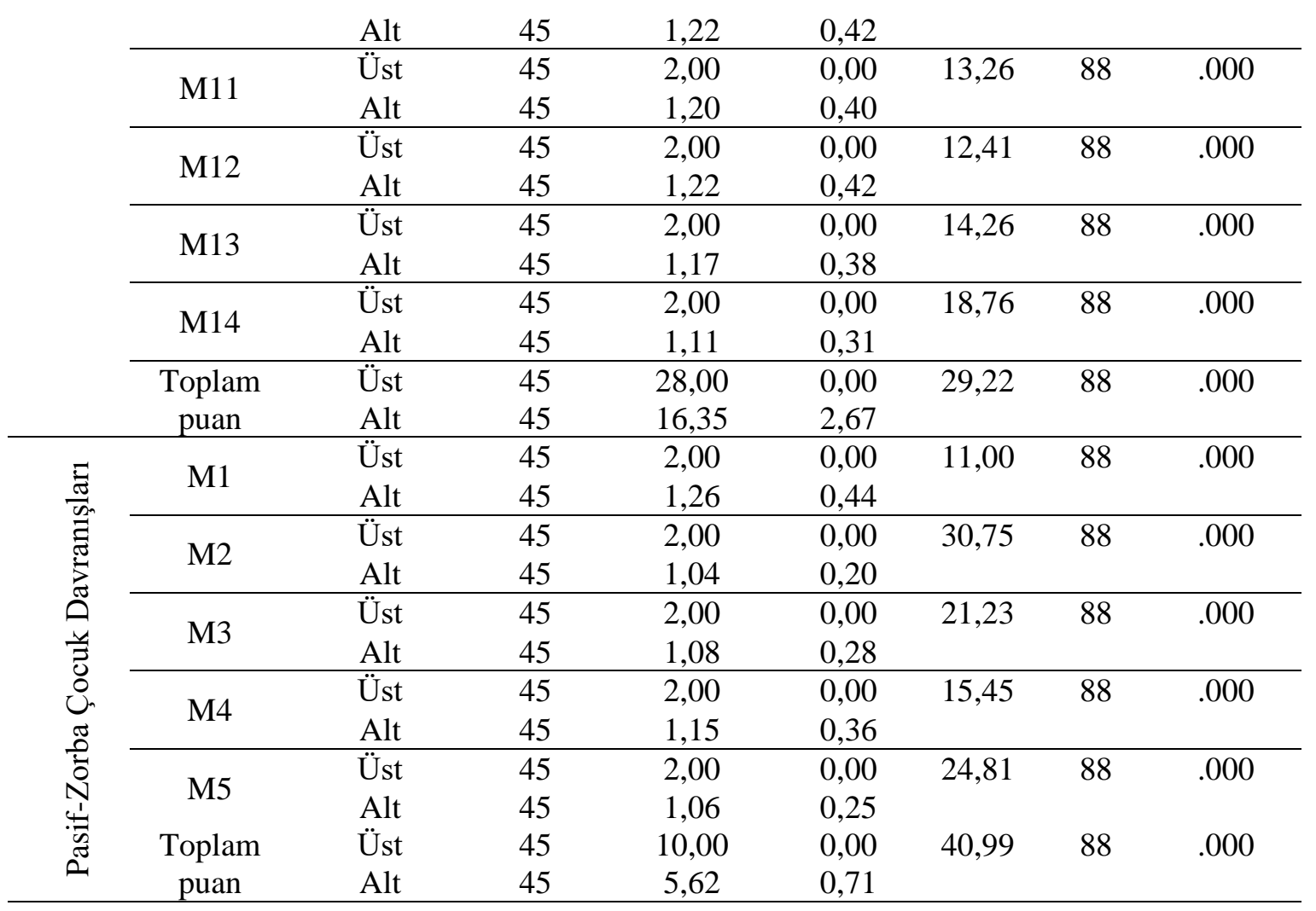

Tablo 7 incelendiğinde, her üç alt boyutta, \%27'lik üst ve alt grupta madde puanlarının manidar düzeyde farklılaştığı görülmektedir $(\mathrm{p}<0,01)$. \%27'lik üst ve alt grupta madde puanlarının farklılaşması yapı geçerliliğinin de bir ölçüsü olarak kabul edilebilir (Baykul, 2015).

\section{Tartışma / Sonuç ve Öneriler}

Araştırmada zorba, kurban ve pasif zorba çocuk davranışlarını değerlendirmeye yönelik bir ölçme aracı geliştirilmesi amaçlanmıştır. Geniş bir alanyazın taraması ve öğretmen görüşmelerinin ardından, akran zorbalığı konusunda üç tür davranış örüntüsü olabileceğine karar verilmiştir. Bunlardan ilki zorba çocuk davranışları, ikincisi kurban çocuk davranışları ve üçüncüsü pasif zorba çocuk davranışlarıdır. Bu bağlamda üç alt boyuttan oluşan bir form hazırlanmasına karar verilmiş ve toplam 32 madde yazılarak uzmanlardan görüş alınmıştır. Uzmanlardan gelen görüşler doğrultusunda maddelerde gerekli düzeltmeler yapılmış ve Karabük İlinde okul öncesi ve ilkokul 1-4. sınıf düzeyinde öğrenim görmekte olan 176 çocuğun öğretmenlerinden veriler toplanmıştır.

Verilerin çözümlenmesinde, üç alt boyutun tümünde KMO değeri ve Barlett'in Küresellik testine göre dağılımın normal çıkmasının ardından, alt boyutların AFA sonuçlarına ilişkin birikinti grafikleri incelenmiş ve alt boyutların tek faktörlü bir yapıyı temsil ettiği görülmüştür. Toplam 13 maddenin yer aldığı Zorba Çocuk Davranışları alt boyutunda faktör yük değerlerinin 0,83 ile 0,67 , Kurban Çocuk Davranışları alt boyutundaki 14 maddenin 0,86 ile 0,67, Pasif-Zorba Çocuk Davranışları alt boyundaki beş maddenin 0,79 ile 0,65 arasında olduğu görülmüştür. Binişik ve düşük faktör yük değeri veren maddelerin olmaması, 32 maddelik üç alt boyuttan oluşan değerlendirme formunun yapıyı iyi bir biçimde temsil ettiğine ilişkin kanıtlar sunmuştur. AFA'dan sonra elde edilen veriler üzerinde DFA uygulanmış ve elde edilen sonuçlara dayalı olarak model uyumunun doğrulandığı sonucuna ulaşılmıştır. Zorba-Çocuk Davranışları alt boyutunda 13 maddenin madde-toplam puan korelasyonlarının 0,64 ile 0,80, Kurban-Çocuk Davranışları alt boyutundaki 14 maddenin 0,83 ile 0,63, Pasif Zorba-Çocuk Davranışları alt boyundaki beş maddenin 0,47 ile 0,64 aralığında değiştiği; üç alt boyutun tümünde, \%27'lik üst ve alt grupta madde puanlarının manidar düzeyde farklılaştığı 
belirlenmiş̧tir $(\mathrm{p}<0,01)$. Bu kanıtlar, maddelerin ölçülen özellik bakımından farklı iki grubu birbirinden iyi derecede ayırabildiği şeklinde yorumlanmıştır. KR-20 iç tutarlılık katsayısı Zorba-Çocuk Davranışları alt boyutunda 0,86, Kurban-Çocuk Davranışları alt boyutunda 0,88 ve Pasif Zorba-Çocuk Davranışları alt boyutunda ise 0,71 olarak hesaplanmıştır. "Zorba ve Kurban Çocuk Davranışlarını Değerlendirme Formu" adı verilen ölçme aracının, her alt boyuttan alınan puanların ayrı ayrı değerlendirilerek okul öncesi ve ilkokul dönemindeki çocukların zorba, kurban ve pasif-zorba çocuk davranışlarının belirlenmesine yönelik çalışmalarda, geçerli ve güvenilir bir ölçme aracı olarak kullanılabileceği kanısına varılmıştır (Ek 1).

Zorbalığı önleyici müdahale programlarının etkisinin sınırlı olduğu göz önünde bulundurulduğunda, erken yaşlardan itibaren risk gruplarının belirlenmesinin oldukça önemli olduğu söylenebilir. Zorbalık davranışları, gelişimsel açıdan kritik bir öneme sahip olan erken çocukluk yıllarından itibaren gerek sosyal becerilerin gerekse problem çözme becerilerinin desteklenmesiyle önlenebilir. Erken yaşlarda risk davranışlarının belirlenmesi, istenmeyen davranışların alışkanlığa dönüşmesi ve kişilik özelliği olarak yerleşmesini önlemek açısından önemlidir. Bu çalışmada geliştirilmiş olan değerlendirme formu, erken çocukluk yıllarında zorba ve kurban çocuk olma risk davranışlarının belirlenmesinde kullanılabilecek geçerli ve güvenilir bir araç olarak kullanılabilir.

\section{Kaynaklar}

Akbaba-Altun, S. ve Erdur-Baker, Ö. (2010). Okuldaki şiddetin etkileri. Çağgaş Ĕ̆itim Dergisi, 35(380), 5-11.

Aydoğan, Y. ve Özyürek, A. (2013). Okul öncesi çocuklarda şiddet davranışları. Uluslararası Aile Çocuk ve Ë̆itim Dergisi, 1(2), 1-18.

Baykul, Y. (2000). Ë̆itimde ve psikolojide ölçme: Klasik test teorisi ve uygulaması, Ankara: ÖSYM Yayınları.

Begde, Z. ve Özyürek, A. (2016). Öğretmen ve anne-baba tutumlarının okul öncesi dönem çocuklarının problem çözme becerilerine etkisi. Amasya Üniversitesi Ĕgitim Fakültesi Dergisi, 5(1), 204-232.

Berkmen, B. ve Okray, Z. (2015). Çocuk istismarı ölçeğinin Türkçe'ye çevirisi, geçerlik ve güvenirlik çalışması. Uluslararası Katılımlı III. Çocuk Gelişimi ve Eğitimi Kongresi "Erken Müdahale". Hacettepe Üniversitesi Sağlık Bilimleri Fakültesi 1 (Özel sayı 2), 242-254.

Brown, T. A. (2014). Confirmatory factor analysis for applied research. Guilford Publications.

Burnukara, P. ve Uçanok, Z. (2012). Okul ortamı ve sanal ortamda meydana gelen akran zorbalığı ne ölçüde örtüşüyor? Türk Psikoloji Dergisi, 27(69), 81-96.

Büyüköztürk, Ş. (2017). Sosyal bilimler için veri analizi el kitabı. Pegem Atıf İndeksi, 1-213.

Cardona, R. S., Reyes, A. S. ve Tangalin, M. M. (2015). The bullying experiences and classroom discipline techniques in an Urban National High School in the Philippines: A basis for an Anti-Bullying Program. American International Journal of Contemporary Research, 5(2), 49-52.

Cho, S. ve Lee, J. M. (2018). Explaining physical, verbal, and social bullying among bullies, victims of bullying, and bully-victims: Assessing the integrated approach between social control and lifestyles-routine activities theories. Children and Youth Services Review.

Cook, C. R., Williams, K. R., Guerra, N. G., Kim, T. E. ve Sadek, S. (2010). Predictors of bullying and victimization in childhool and adolescence: A meta-analytc investigation. School Psychology Quarterly, 25(2), 65-83.

Costley, J. H. M., Sueng-Lock, H. ve Ji-Eun, L. (2013). Preservice teachers'response to bullying vignettes: The effect of bullying type and gender. International Journal of Secondary Education, 1(6), 45-52.

Çokluk, Ö., Şekercioğlu, G. ve Büyüköztürk, Ş. (2014). Sosyal bilimler için çok değişkenli istatistik: SPSS ve LISREL uygulamaları. Pegem Akademi. 
Delaney-Black, V., Covington, C., Ondersma, S. J., Nordstrom-Klee, B., Templin, T., Ager, J., Janisse, J. ve Sokol, R. J. (2002). Violence exposure, trauma, and IQ and/or reading deficits among urban children. Arch Pediatr Adolesc Med., 156, 280-285.

Elliott, S. N., Hwang, Y. S. ve Wang, J. (2019). Teachers' ratings of social skills and problem behaviors as concurrent predictors of students' bullying behavior. Journal of Applied Developmental Psychology, 60, 119-126.

O. Emre (Çev. Ed.). (2017). 0-3 yaş çocuk gelişimi, gelişim psikolojisinin temel esasları I. Ankara: Anı Yayıncilik.

Eslea, M. ve Smith, P. K. (2000). Pupil and parent attitudes towards bullying in primary schools. European Journal of Psychology of Education, 15(2), 207-219.

Flannery, D. J., Wester, K. L. ve Singer, M. I. (2004). Impact of exposure to violence in school on child and adolescent mental health and behavior. Journal of Community Psychology, 32, 559-573.

Gini, G. ve Pozzoli, T. (2013). Bullied children and psychosomatic problems: A meta-analysis. Pediatrics, 132(4), 720-729.

Gültekin-Akduman, G. (2012). Okul öncesi dönemde akran zorbalığının incelenmesi. Toplum ve Sosyal Hizmet, 23(1), 121-138.

Gültekin, Z. ve Say1l, M. (2005). Akran zorbaligini belirleme ölçegi gelistirme çalismasi. Türk Psikoloji Yazıları, 8(15), 47-61.

İlhan-Alper, S. (2008). İlkögrretimde zorbalık (Yayımlanmamış yüksek lisans tezi). Uludăg Üniversitesi, Sosyal Bilimler Enstitüsü, Bursa.

İşmen, A. E. (2004). Aile içi çocuk istismarı ölçek geliştirme çalışması. Hasan Ali Yücel Eğitim Fakültesi Dergisi, 1, 207-221.

Kapcı, E. G. (2004). İlköğretim öğrencilerinin zorbalığa maruz kalma türünün ve sıklı̆̆ının depresyon, kaygı ve benlik saygısıyla İlişkisi. Ankara Üniversitesi Ĕ̈itim Bilimleri Dergisi, 37(1), 1-13.

Karaman-Kepenekçi, Y. K. ve Çınkır, S. (2006). Bullying among Turkish high school students. Child Abuse \& Neglect, 30, 193-204.

Karataş, H. (2011). Illköğretim okullarında zorbalı̆̆a yönelik geliştirilen programın etkisinin incelenmesi (Yayımlanmamış doktora tezi). Dokuz Eylül Üniversitesi, İzmir.

Kartal, H. (2009). The ratio of bullying and victimization among turkish elemantary school students and its relationship to gender and grade level. Journal of Social Science, 20(2), 109-119.

Kılıç, E. Z. (2012). Ergenlerde şiddet kullanımı: Bireysel ve ailesel etkenler. Nöropsikiyatri Arşivi, 49, 260-265.

Krygsman, A. ve Vaillancourt, T. (2019). Peer victimization, aggression, and depression symptoms in preschoolers. Early Childhood Research Quarterly, 47, 62-73.

Kutlu, F. (2005). The effect of bullying management training on bullying behaviours of elementary school students (Ph.D. Thesis). Middle East Technical University, Ankara.

Ladd, G. W. (1990). Having friends, keeping friends, making friends, and being liked by pers in the classroom: Predictors of children's early school adjustment? Child Development, 61, 1081-1100.

Olweus, D. (2003). A profile of bullying at school. Educational Leadership,60(6), 12-17.

Özyürek, A., Yavuz, N. F. ve Begde, Z. (2014). Okul öncesi çocukların sosyal beceri ile çevresindeki yetişkin etkileşimleri arasındaki ilişki. Afyon Kocatepe Üniversitesi Sosyal Bilimler Dergisi, 16(2), 115-134.

Pekdoğan, S. (2016). Annelerin istismar potansiyellerinin bazı değişkenler açısından incelenmesi. Ege Ĕgitim Dergisi, 2, 425-441.

Pekel-Uludağlı, N. ve Uçanok, Z. (2005). Akran zorbalığ 1 gruplarından yalnızlık ve akademik başarı ile sosyometrik statüye göre zorba/kurban davranış türleri. Türk Psikoloji Dergisi, 20(56), 77-92.

Pişkin, M. (2002). Okul zorbalığı: tanımı, türleri ve ilişkili olduğu faktörler ve alınabilecek önlemler. Kuram ve Uygulamada Eğitim Bilimleri, 2(2), 531-562. 
Rupp, S., Elliott, S. N. ve Gresham, F. M. (2018). Assessing elementary students' bullying and related social behaviors: Cross-informant consistency across school and home environments. Children and Youth Services Review, 93, 458-466.

Satan, A. (2006). Illköğretim ikinci kademe öğrencilerinin zorba davranış eğilimlerinin okul türü ve bazı sosyo demografik değişkenler ile ilişkisi (Yayımlanmamış Doktora tezi). Marmara Üniversitesi, İstanbul.

Swearer, S. M. ve Hymel, S. (2015). Understanding the psyhology of bullying, moving toward a social-ecological diathesis-stress model. American Psychologist, 70(4), 344-353.

Szewczyk-Sokolowski, M., Bost, K. K. ve Wainwright, A. B. (2005). Attachment, temperament and preschool children's peer acceptance. Social Development, 14(3), 379-397.

Tabachnick, B. G., Fidell, L. S. ve Osterlind, S. J. (2001). Using Multivariate Statistics.

Topçu-Kabasakal, Z. (2005). Aile içindeki şiddetin çocuktaki uyum sorunlarıyla bağlantısı. Dokuz Eylül Üniversitesi Buca Eğitim Fakültesi Dergisi, 18, 24-26.

Turan, S., Çubukçu, Z. ve Girmen, P. (2010). Patterns and forms of violent behaviors encountered among pupils in Turkish public schools. Eğitim ve Insani Bilimler Dergisi/Teori ve Uygulama, 1, 53-74.

Uysal, H. ve Dinçer, Ç. (2012). Peer bullying during early childhood. Kuramsal Eğitimbilim Dergisi, 5(4), 468-483.

Yurtal, F. ve Cenkseven, F. (2007). İlköğretim okullarında zorbalığın yaygınlığı ve doğası. Türk Psikolojik Danışma ve Rehberlik Dergisi, 3(28), 1-12.

Yücel, D. ve Işıkcı, G. (2017). Okul ve suçluluk. D. Yücel ve M. B. Gönüllaş (Çev.Ed.). Çocuk Suçluluğu. 9.basımdan çeviri. Ankara: Nobel.

Ziyalar, N. ve Çalıcı, C. (2017). Ergenlik ve suçluluk. D. Yücel ve M. B. Gönüllaş (Çev.Ed.). Çocuk Suçluluğu. 9.basımdan çeviri. Ankara: Nobel.

\section{Extended Abstract}

\section{Introduction}

The most important cause of violence, which is an individual, social and educational problem, is considered as the social relations in a society. In addition to biological and learning factors, factors such as rapid urbanization, increase in schooling rate have an impact on the prevalence of violence. Especially the prevalence of violence at school, which is described as peer bullying, has been increasing. Bullying involves direct behavior such as mockery, menace, teasing, hitting, and stealing initiated against a weak victim by one or more violent students. Global studies demonstrated that bullying leads to negative consequences for students of all ages and sexes, both for the bully and the victim. Exposure to peer bullying is a risk factor for the future life of the child with respect to psychological and adjustment problems. This fact suggests that peer bullying problem should be seriously addressed.

Determination of the child behavior in peer relations from pre-school years to adolescence and taking preventive measures for possible problems that can be experienced starting from adolescence are significant for early intervention during the times of increasing incidence of violence. Identification of bullying and victim behavior in children in early ages is important to prevent peer bullying. Thus, the present study aimed to develop a measurement instrument to assess the bully and victim child behavior.

\section{Methodology}

The study group included 176 pre-school and primary school teachers. During the development of the measurement instrument, initially the literature was reviewed and interviews were conducted with two pre-school and two primary school teachers and the possible indicators of bullying behavior in children were determined. It was concluded that the first sub-dimension would be "Bully-Child Behavior", the second sub-dimension would be "Victim-Child Behavior" and the third sub-dimension would be "Passive Bully-Child Behavior". Views of 7 field experts were obtained to determine the suitability of the items for the objective and their clarity for 
content validity. The form that included 32 items was then finalized for application. After a pilot scheme was conducted with a small group, the actual application was initiated. Analysis demonstrated that the data distribution was normal in all three sub-dimensions based on the KMO value and Barlett's test of sphericity. Cumulative graphs for the Exploratory Factor Analysis results were examined and it was observed that the sub-dimensions reflected a singlefactor construct. Explanatory and Confirmatory Factor Analyzes were conducted KR-20 internal consistency coefficient was calculated to determine the scale validity and reliability. In addition, the differences between items mean scores, and factor means of the upper $27 \%$ and lover $27 \%$ are examined by the t-test.

\section{Results}

It was determined that the "Bully and Victim Child Behavior Assessment Scale" included 32 items and 3 sub-dimensions, namely "Bully Child Behavior", "Victim Child Behavior" and "Passive Bully Child Behavior". Factor loads in Bully Child Behavior subscale that included 13 items were between 0.83 and 0.67 , factor loads were between 0.86 and 0.67 for the 14 items under Victim Child Behavior subscale, and factor loads were between 0.79 and 0.65 for the 5 items in the final subscale of Passive-Bully Child Behavior.

Fit index values of one factor model in Bully Child Behavior subscale indicate good fit $[\chi 2(\mathrm{sd}=65)=205 ; \chi 2 / \mathrm{sd}=3,15 ; \mathrm{GFI}=.85, \mathrm{CFI}=.96 ; \mathrm{RMR}=.01 ; \mathrm{SRMR}=05]$. Fit index values of one factor model in Victim Child Behavior subscale indicate good fit $\left[\chi^{2}(\mathrm{sd}=77)=278\right.$; $\chi 2 / \mathrm{sd}=3,56 ; \mathrm{GFI}=.82, \mathrm{CFI}=.96 ; \mathrm{RMR}=.01 ; \mathrm{SRMR}=05]$. Fit index values of one factor model in Passive Bully Child Behavior subscale indicate good fit $[\chi 2(\mathrm{sd}=5)=18,6 ; \chi 2 / \mathrm{sd}=3,7 ; \mathrm{GFI}=.96$, $\mathrm{CFI}=.95 ; \mathrm{RMR}=.01 ; \mathrm{SRMR}=05]$. It is expected that $\mathrm{RMR}$ values will be close to 0 , and the values that are equal to 0.05 or less indicate a good fit. When the values of CFI is over 0.95 , it indicates a very good fit. The results of CFA showed that fit indices of onefactor model was at an acceptable level.

The lack of items with overlapping and low factor loads provided evidence that the scale that included three subscales and 32 items represented the construct well. Scale KR-20 internal consistency coefficient was calculated as 0.86 for Bully Child Behavior subscale, 0.88 for Victim Child Behavior subscale and 0.71 for Passive Bully Child Behavior subscale. For each factor and each item, the differences between mean scores of upper $27 \%$ and lover $27 \%$ groups are significant $(\mathrm{p}<.01)$.

\section{Conclusion}

Determination of risk behavior at early ages is important to prevent undesired behavior from turning into habits and becoming personality traits. It was concluded that the scale can provide valid and reliable evidence for identification of bully, victim and passive-bully children during pre-school and primary school ages.

\section{EK-1}

Zorba ve Kurban Çocuk Davranışlarını Değerlendirme Formu

\begin{tabular}{|ll|c|c|}
\hline Maddeler & Evet & Hayır \\
\hline Z1. & $\begin{array}{l}\text { S1klıkla arkadaşının oynadığı oyuncağı veya bir eşyasını zorla elinden } \\
\text { alır. }\end{array}$ & & \\
\hline Z2. & Genellikle arkadaşlarına ait malzemelere zarar verir (yırtar, kırar vb.) & & \\
\hline Z3. & $\begin{array}{l}\text { Sıra olmayı gerektiren durumlarda, daima sıradaki arkadaşını iterek onun } \\
\text { önüne geçmeye çalışır. }\end{array}$ & & \\
\hline Z4. & $\begin{array}{l}\text { Çoğu zaman haksız olduğu durumlarda da haklı çıkmak için arkadaşına } \\
\text { bağırır. }\end{array}$ & $\begin{array}{l}\text { Genellikle arkadaşlarıyla ilişkilerinde alaycıdır (dalga geçer, isim takar } \\
\text { vb.) }\end{array}$ & \\
\hline Z5. & & \\
\hline
\end{tabular}




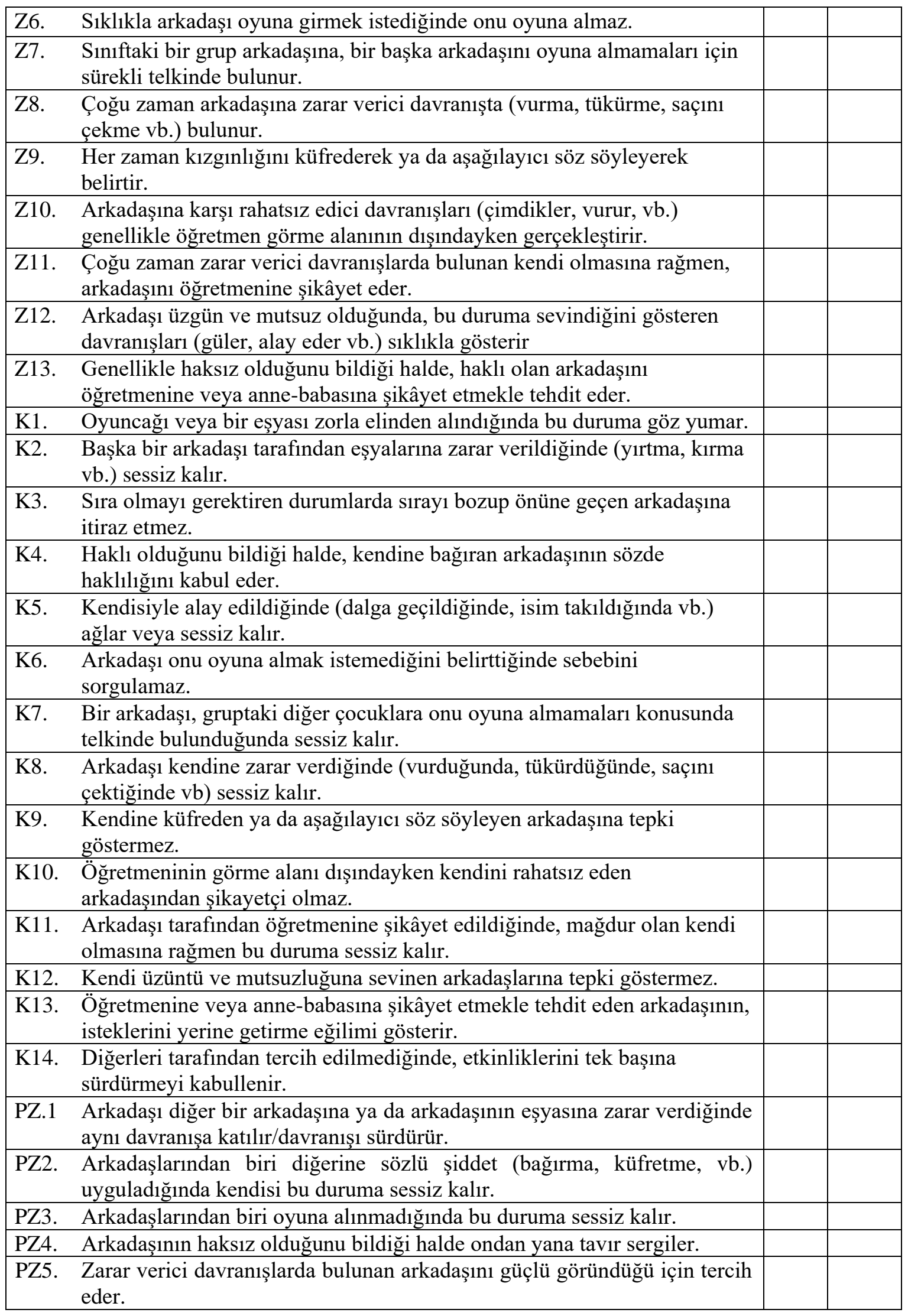

